\title{
Preface
}

\section{to First Edition}

More than twenty-five years have passed since the publication of George Munro's Birds of Hawaii, and there is a need for an up-to-date book on the birds of the Hawaiian Islands, if for no other reason than to chronicle the continual desecration of the unique $\mathrm{Ha}$ waiian forests and their animal life.

I have received considerable pleasure from the creativity involved in writing this book. Part of the pleasure resulted from the memories of notable field trips in Hawaii between 1964 and 1970. I recall the feeling of freedom and well-being when sitting atop Miller's Peak on Nihoa, scanning the endless blue Pacific on a nearly cloudless day, and then of looking down the steep slopes at the many thousands of seabirds and at Gene Kridler netting Nihoa Finches. I remember exhilarating days and nights on Laysan-of swatting flies on the beach as Nelson Rice and I talked of many things; of the night that Ron Walker and I donned headlamps in order to search for roosting Laysan Finches. There was the cold January day I saw my first Crested Honeycreeper on the northeast slope of Haleakala-a day when the rain fell continuously in sheets; when the fog was so thick we could scarcely see across tiny Lake Wai Anapanapa; when the temperature did not rise above $45^{\circ} \mathrm{F}$; and when John Maciolek, Dave Kawate, Joe Medeiros, and I were so cold we could hardly eat our lunch. I remember clearly the first trek into the Alakai Swamp country with Mike Ord, Ron Walker, and Warren King. Rarely in any part of the world have I seen such a beautiful, aweinspiring, pristine area as the Alakai; the bulldozer cannot reach it, but exotic plants could destroy it. My admiration for the crew of the Bureau of Commercial Fisheries' ship the Charles $H$. Gilbert has not waned one bit since they skillfully got us and our equipment on and off Nihoa Island during the summer of 1966; these men did not bat an eye as they were bounced about in their skiff, surrounded by churning white water in
Adams Bay, as we pulled all our gear ashore by ropes from mid-morning until late afternoon.

I also remember days and nights, however, when my emotions ranged from frustration to depression and to disgust as I recalled my repeated, futile efforts to find certain Hawaiian birds after reading of Hawaii as it was in the $1890 \mathrm{~s}$. That the Hawaiian biota should have been raped, ravaged, and devastated during the nineteenth century was regrettable even though understandable, but that this rape has continued not only into the twentieth century but even into the eighth decade of that century is a sad commentary on man as an animal species. Man is, indeed, a disease on the planet earth.

Few people realize how ignorant we are to this day about the basic facts of the breeding biology of the endemic Hawaiian birds. There are historical reasons, of course. The nineteenth century was a period of discovering new birds and of describing and naming them. Some of the early collectors also were plagued by tragedy. William Anderson, the surgeon-naturalist on Captain Cook's last voyage, died on August 1, 1778, and most of the specimens collected on Cook's voyages have been lost. To be sure, William Ellis, an "'assistant surgeon," painted 12 species of Hawaiian birds and John Webber painted 7, but apparently only seven of these works have ever been published (Medway 1981). Ellis' watercolor paintings are described as having "considerable charm and delicacy.,"

Andrew Bloxam made collections during the visit of H.M.S. Blonde in 1824 and 1825, but his collection also was lost. There was a published natural history report of the voyage, but Alfred Newton wrote that "an appendix there indeed is, but one utterly unworthy of its reputed author, for the book was edited by a lady who had nothing but a few of his notes to guide her, and though assisted, as it is stated, by 'the gentleman connected with that department in the British Museum' 
the Appendix is a disgrace to all concerned, since, so far from advancing the knowledge of the subject, it introduced so much confusion as to mislead many subsequent writers" (Henshaw 1902:74). Similarly, the American naturalist J. K. Townsend collected in Hawaii in 1835, but Henshaw remarked that "our gain in knowledge of the avifauna of the islands resulting from the visits of these three investigators was comparatively little. Nothing was published by the investigators themselves," and, therefore, published material dealt almost exclusively with technical descriptions of the birds, with little or no reliable information on distribution, behavior, or breeding habits. Indeed, the labels on most of the specimens gave the region of collection simply as the "Sandwich Islands," typically with no other information.

Perhaps the most significant of the early collections was made by Charles Pickering and Titian Peale, who visited the islands during 1840 with the United States Exploring Expedition. However, nearly all of the specimens were lost in the wreck of one of their ships. Moreover, "of the original report upon the mammals and birds by Peale, nearly all the copies were destroyed by fire." There must be an interesting story to explain why John Cassin published a revised edition of Peale's work ten years later.

The first important list of Hawaiian birds was published by Sanford B. Dole in 1869 (corrected and republished in 1879); it covered about half of the species found in the islands.

British colonial servants and army physicians made significant studies of the flora and fauna in many faraway places during the nineteenth century. How unfortunate it is that none of the early missionaries in Hawaii, such as William Ellis, C. S. Stewart, and Titus Coan, apparently had any interest in the birdlife. Each man wrote about his experiences in Hawaii, including trips to the Kilauea volcano, but birds were ignored in the writing. The highly respected Hawaiian scholar David Malo (born on Hawaii about 1793) did leave a written record (Hawaiian Antiquities, or Moolelo Hawaii) telling much of Hawaiian history and culture. Malo's book was translated from Hawaiian into English by Nathaniel B. Emerson in 1898 and was published by the Bernice P. Bishop Museum in 1951. In his biographical sketch of Malo, Emerson wrote that "such good use did Malo make of his opportunities that he came to be universally regarded as the great authority and repository of Hawaiian lore." Malo wrote that the Hawaiians ate the following species of birds: Newell's Shearwater, Dark-rumped Petrel, Bulwer's Petrel, Hawaiian Stilt, Golden Plover, Bristle-thighed Curlew, Coot, Hawaiian Rail, Crow, Elepaio, Oo, Mamo, Iiwi, Amakihi, and Akialoa. Nevertheless, it is clear from reading Malo's comments on the endemic forest birds that he had little or no personal knowledge of them because there are many errors in his descriptions.

In his Sandwich Island Notes, Bates (1854) mentioned only one bird (Apapane) by name. Similarly, I was also greatly disappointed in reading Isabella L. Bird's Six Months in the Sandwich Islands to learn that she apparently found the birds not worth writing about. She was a skilled horsewoman, and covered Hawaii in 1873 as few if any foreigners have ever done. She described the ferns and other plants repeatedly and at great length, but had hardly a word for the birds. What I cannot comprehend is how such an observant woman, traveling alone with a Hawaiian guide and living in the homes of the Hawaiian people, could have shown no interest in the islands' remarkable birds, but this is part of the historic reason for our ignorance of Hawaiian birds.

The modern era of Hawaiian ornithology began in 1887, when Scott Wilson, an Englishman, began his work in Hawaii, and all of the important work done in Hawaii from that time to the turn of the century was done because of the interest in the Hawaiian avifauna by the English. Lord Walter Rothschild sent Henry Palmer to collect in the Hawaiian Islands from December 1890 to August 1893; George C. Munro was one of Palmer's assistants. The Royal Society and the British Association for the Advancement of Science sent R. C. L. Perkins to Hawaii in 1892. Perkins, an entomologist, was a keen field observer, and it is to him primarily that the first knowledge of the habits of the birds is attributed. He studied the land fauna for ten years. Despite the highly significant contributions made by Perkins, Henshaw could justifiably write in 1902:

"Notwithstanding the important contributions of the English naturalists, there is still offered an inviting field for future study and investigation. . . . Of the nests and eggs of Hawaiian birds we know next to nothing.",

Henshaw added that he had prepared his list of $\mathrm{Ha}$ waiian birds "chiefly with the hope that the meagerness of our knowledge respecting this subject may thereby be made more apparent, and thus that island observers may be stimulated to enter this very interesting and fruitful field-a field, too, which it would seem should appeal particularly to the pride and interest of the residents of the islands." He wrote in vain.

As long ago as the turn of the century, Henshaw (1902:71-73) also bemoaned the lack of interest of the Hawaiians in the birdlife.

The impression seems to be general that in olden times the natives were extensively acquainted with Hawaiian birds, 
which is true, and that even the present day natives are very well posted on the subject; the latter is by no means the case. . . . In the olden days when it was an important part of their duty for the priests to watch the motions of certain birds and listen to their songs that by this means they might learn the will of the Gods, and when the bird-catcher plied his calling that the feather tribute might not be wanting to pay the taxes imposed by the chiefs, then we may be sure bird-lore was well-nigh universal.

The bird-catchers, especially, must have been thoroughly familiar not only with the haunts of all the feathered kind, but with their songs and their habits.

But taxes are no longer payable in feathers; no longer does the bird-catcher ply his calling; the priest no more reads auguries from the songs of birds; the old days have gone forever, and with the old days and the old conditions have gone the greater part of Hawaiian bird-lore.

Now in the eighth decade of the twentieth centurywhen overpopulation and pollution of the environment threaten the very existence of mankind-presidents, governors, and legislators may listen to scientists, but it has not long been so. When George C. Munro made his pleas and his predictions, few listened, and he was by no means the first to make such pleas.

Writing in the Ibis in 1890, Scott Wilson said:

I have gone at some length into this question, as, by so doing, I may draw it to the attention of the Hawaiian Government, as well as that of the large land-owners, and their combined action cannot be too soon brought into effect if the entire disforestation of the Hawaiian Archipelago is to be prevented. It would be a disgraceful thing if such a Garden of Eden should be bereft of its birds, more especially as I am convinced that these islands have a great future before them as the great health-resort for the inhabitants of San Francisco flying from its unhealthy and treacherous climate, to say nothing of the vast number of tourists who will flock, in yearly-increasing numbers, to see the volcanic wonders of Hawaii, from all quarters of the globe. All these visitors may be expected to take an intelligent interest in the avifauna of the islands they visit or make their home, and on their behalf I appeal to the land-owners and to the Legislature of Hawaii to unite in protecting their country's birds. I would suggest that not only should forestlands be fenced in so far as practicable, but that no exotic birds should be introduced. Several species of Hawaiian birds, which were to be found in Cook's time, and others which were obtained even so late as 1840 , have become extinct, and it would not be rash to say that ere another century has elapsed but few native species will remain.

To be sure, not all the "sophisticated" modern visitors "take an intelligent interest in the avifauna of the islands,"' but vast numbers of tourists we do have, and there are all too few remaining virgin forests and native birds for those visitors who have an interest in nature.

Twenty years remain of the 100 -year period men- tioned by Wilson in 1890, and many more Hawaiian birds have become extinct since then. It is now reasonable to expect that Wilson's predictions will, indeed, come true unless there is an immediate change in attitude among the state's elected officials toward the value of our endemic flora and fauna.

In the interest of truth, it also seems appropriate to dispense with the widespread myth that the Hawaiians were conservationists. They were neither better nor worse than peoples in other parts of the world (see Stonehouse 1962b), but work to preserve the endemic birds they undoubtedly did not do. When Captain Cook discovered Kauai on January 20, 1778, among the articles brought to barter were "great numbers of skins of small red birds [Vestiaria coccinea] which were often tied up in bunches of 20 or more, or had a small wooden skewer run through their nostrils"' (Stresemann 1950:78). Many other examples of the use of birds as food and for their feathers are given in the present book.

Figures 1 and 2 are included to aid the reader in understanding the ornithological terms used in describing plumage patterns, and especially those which provide distinctive "field marks" for identifying birds in the wild.

I am pleased to acknowledge the excellent cooperation of a number of people in the preparation of the text and illustrations, and I express my sincere appreciation to them:

To Dr. Roland W. Force, director of the Bernice P. Bishop Museum, for permission to use the color plate from the fine paper by Frank Richardson and John Bowles, and for his kindness in allowing me to borrow study skins from the museum's collection. To Edwin H. Bryan, Jr., Curator of Collections at the museum, for generously allowing me to use a draft manuscript of his revised Check List and Summary of Hawaiian Birds. To Miss Margaret Titcomb, Museum Librarian, for providing photographs from the Tanager Expedition and from Rothschild's unpublished work.

To the following people for providing photographs, either for use in the book or in preparation of the original paintings: Norman Carlson, Sherwin Carlquist, C. Robert Eddinger, Warren B. King, Eugene Kridler, David L. Olsen, W. Michael Ord, John L. Sincock, Herman T. Spieth, P. Quentin Tomich, Richard C. Tongg, Lewis Wayne Walker, Ronald L. Walker, and William O. Wirtz II. I am especially grateful to Alfred M. Bailey for providing photographs taken by him and by Walter K. Fisher on Laysan Island in 1902 and 1912-1913. Acknowledgment is given in the legend for each of the photographs; those not so acknowledged were taken by me. 


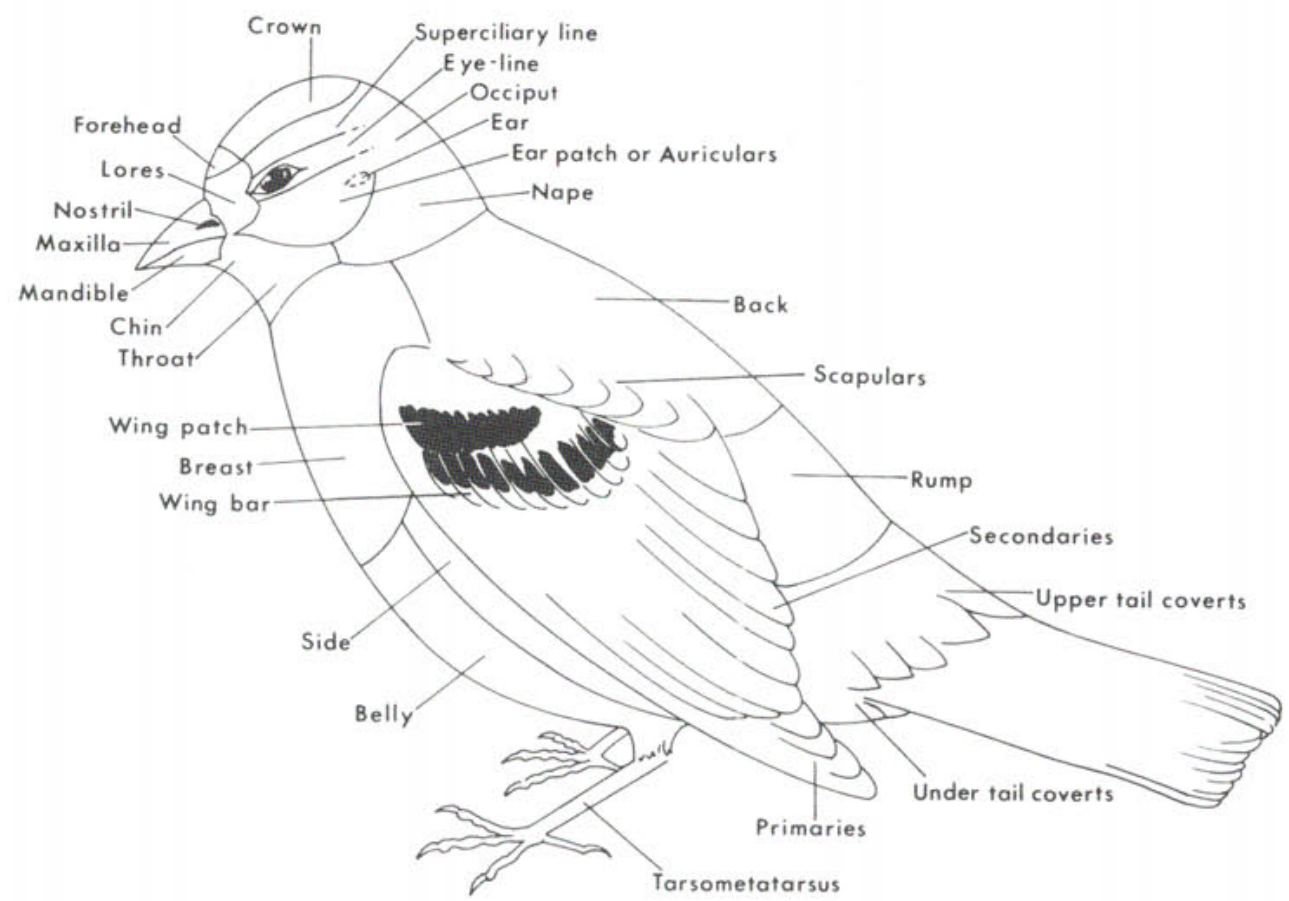

FIGURE 1. The topography of a bird.
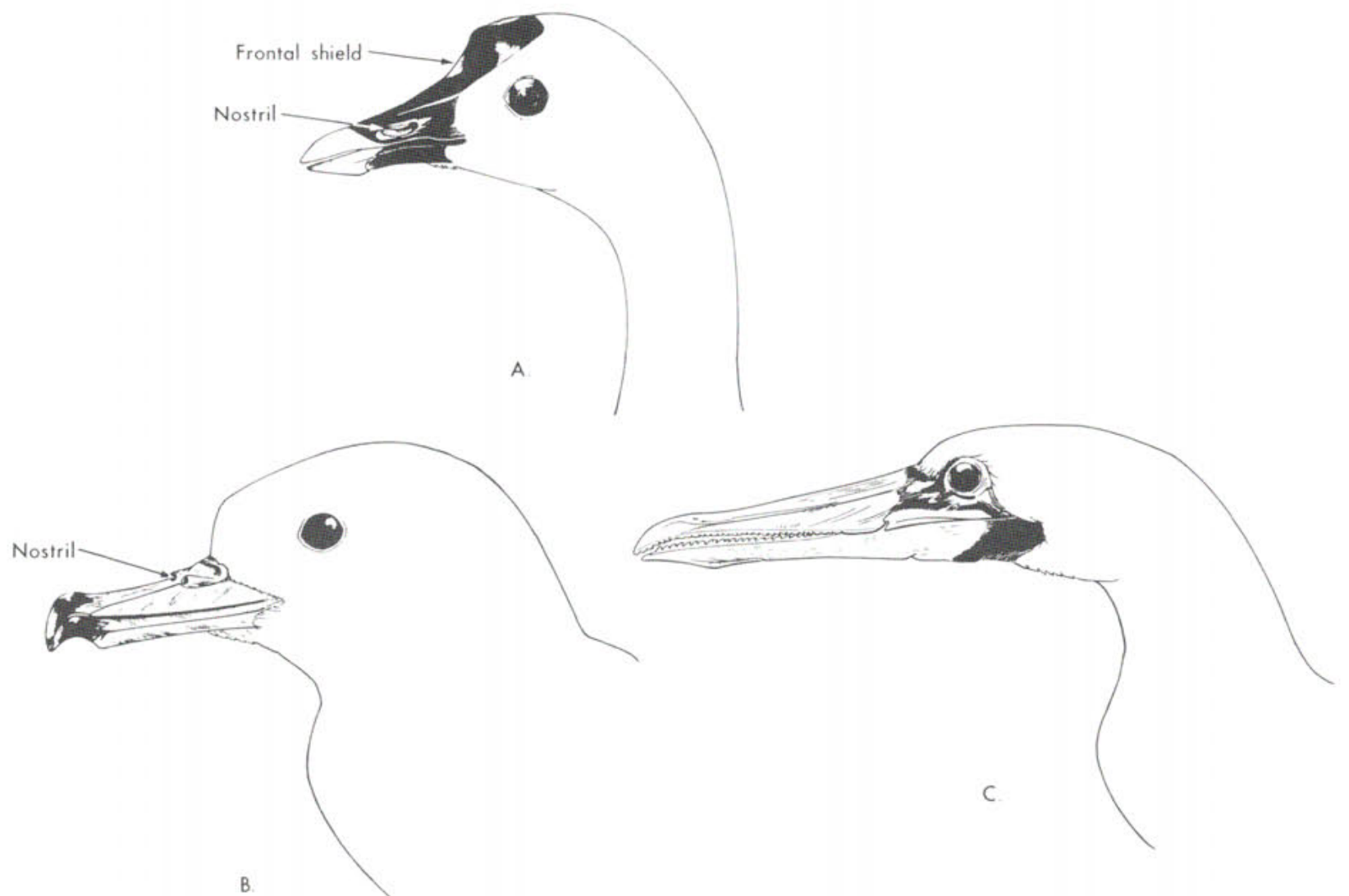

FIGURE 2. Special features of the heads of three birds: $A$, Gallinule; $B$, Wedge-tailed Shearwater; $C$, Red-footed Booby, in which species there are no external nostrils. 
To Charles H. Lamoureux and William J. Hoe for analyzing the plant constituents of several bird nests. To Allen Y. Miyahara, Frank H. Haramoto, and Frank J. Radovsky for identifying bird parasites and diseases.

To Eugene Kridler, manager of the Hawaiian Islands National Wildlife Refuge, for his kindness in inviting me to accompany him on two expeditions to the Leeward Islands, for making it possible for me to raise Nihoa Finches in captivity, and for providing unpublished data on migrant species.

To Ronald L. Walker and David H. Woodside, of the State Division of Fish and Game, who were most generous in providing me unpublished material on both game birds and nongame species, as well as for being congenial and highly competent field companions for trips from Hawaii to Midway Atoll.

To Mrs. Virginia C. Cone who, in addition to giving valuable assistance in proofreading at each stage of book production, was deeply concerned about the fate of the endemic Hawaiian birds, was inspired by the skylark, and was continually insistent that the Common Mynah was a good introduction to Hawaii.

To Miss Sue Monden, who displayed great interest in painting the original color plates from fresh plant materials and bird skins, and, for several species of honeycreepers, from birds that C. Robert Eddinger and I raised in captivity.

To Miss Linda N. Tanaka and Mrs. Sally S. Oshiro for their meticulous typing of the manuscript.

A grant from the Research Administration of the University of Hawaii and, later, National Science Foundation Grant GB-5613 provided the necessary funds for interisland travel for my studies of Hawaiian birds.

ANDREW J. BERGER
October 1970 



\section{Hawaiian Birdlife}


